\title{
LETTERS
}

\section{Canada Health Act: defend or reform}

The Canada Health Act appears to me to be clear in both its intent and purpose. ${ }^{1}$ It leaves little room for the establishment of alternative providers, essentially only for noninsured purposes (routine magnetic resonance imaging not being one of them). If the government is serious, then it needs to support and prosecute the act.

The rationale behind the lack of alternatives is less clear. Such systems work well in other socialized medicine systems. In recent years, we have seen the gradual erosion of the act, with more and more nonprosecuted violations. When this occurred with the use of cannabis, the government decided to amend the law.

Dr. Philpott needs to decide if the act is fit for purpose, and defend it, or if it is time to reform it in the light of "changing public opinion," as was the case with cannabis. The current standing is untenable.

\section{Jonathan A. Norton PhD BSC}

Assistant professor, University of Saskatchewan, Saskatoon, Sask.

Cite as: CMAJ 2017 January 30;189:E170. doi: 10.1503/cmaj.732487

\section{Reference}

1. Sibbald B, Stanbrook MB. Canada Health Act needs bite. CMAJ 2016;188:1133. 